intensive dialogue is necessary for the integration of a foreignmodeled institution into a national higher education system. Two national quality approaches to the programs offered have to be respected. The expectations of stakeholders with respect to success factors of a foreign-backed institution need to be coordinated. Whereas the founders may tend to favor high enrollment as well as the involvement of industry, applied research, and consultancy, the academic patrons may rather be interested in high teaching standards and academic rather than entrepreneurial ownership of institutional development. If foreign-backed provision works well, however, it offers an opportunity for amalgamation and adaptation of different national types of teaching and higher education organization to engender truly "transnational" higher education.

\section{Academic Freedom in Muslim Societies}

\section{RICHARD KRAINCE}

Richard Kraince directed Ohio University's Inter-Religious Dialogue Project from 2003 to 2006. He will begin a new position as assistant professor of Southeast Asian Humanities at El Colegio de México in Fall 2008. E-mail: kraincer@ohio.edu.

$T^{t}$ has been nearly i5 centuries since Plato's Academy became 1 a casualty of religious zealotry. Emperor Justinian's efforts to impose a standardized version of Christianity throughout the Byzantine Empire resulted not only in widespread persecution of religious minorities but also in the closure of the classical world's preeminent academic institution, after 900 years of educational activity. In this era, the tragedy evolved from (I) the bitter contestation between emergent socioreligious movements, (2) the arrival of a ruling elite eager to side with a particular religious faction rather than to enforce tolerance among competing groups, and (3) the identification of free inquiry as a threat to the consolidation of theocratic rule. Today, as globalization has enhanced the potential of religion to become a source of conflict, scholars in different societies continue to face persecution for pursuing lines of thought at odds with religio-political forces.

In many Muslim societies academic freedom is now a particularly important topic of debate. It can be defined as the right of scholars to pursue intellectual inquiry and to comment publicly without the threat of reprisal on matters within their areas of expertise. Although frequently conflated with the ongoing Danish cartoon controversy-essentially a protracted dispute over what constitutes hate speech-debates over academic freedom in Muslim societies involve efforts to establish the traditions of empirical analysis and critical thought that have been central to the success of dynamic societies across the globe. Like Justinian's forces, however, some Islamic political groups view the establishment of these traditions as a threat to their efforts to dominate social order.

\section{ISLAM AND AUTHORITARIANISM}

The major obstacle to building respect for academic freedom in Muslim societies is the persistence of authoritarian culture. Given that most Muslim-majority countries remain under a form of authoritarian rule, Muslim academics largely face the same kinds of pressures that scholars confront in other authoritarian states. In Syria, Sudan, and Saudi Arabia, for example, regime leaders dominate university governance and restrict campus environments in much the same way that secular regimes endeavor to control academia in Belarus, Ethiopia, and Burma. It is thus unsurprising that the opponents of academic freedom in all of these countries tend to question the appropriateness of critical intellectualism most stridently when demands for freedom of political expression are raised.

In Muslim societies, to a unique extent, religio-political ideology has come to animate both authoritarian powers and opposition groups. Regime leaders commonly call on favored

Given that most Muslim-majority countries remain under a form of authoritarian rule, Muslim academics largely face the same kinds of pressures that scholars confront in other authoritarian states.

clerics for support, while consortia of Islamic groups-some with histories of violent resistance-constitute major forms of political opposition. Since all sides eagerly seek to build constituencies within the higher education community, the struggle for academic freedom is often overshadowed by political conflict. In Egypt, Pakistan, and Algeria, for example, authoritarian regimes have greatly curtailed campus freedoms to limit the influence of Islamic resistance groups. Similarly, in countries where Islamists have gained control as in present-day Iran (or in Pakistan during the rule of General Mohammed Zia-ul-Haq from I977 to I988), campus controls are intended to restrict the activities of secular forces. The common theme in nearly all of these situations includes not simply the domination of the academy but the use of religion as a means to justify the persecution of scholars who dare to question the legitimacy of religio-political authority.

\section{Persecution}

The persecution of scholars takes many forms. In some cases, faculty members have been targeted by shadowy militias, as was Humayun Azad, who was a professor of language and literature at the University of Dhaka in Bangladesh. The eminent professor was an expert on Bengali linguistics and authored 
scores of publications, including one of the first serious books on women's issues in Bangladesh. He narrowly survived a machete assault by a group of thugs in 2004 after depicting both Islamist and nationalist extremists as objectionable characters in a recently published novel. Azad died six months later in Germany, where he had fled to escape further attacks.

In other cases, the infringement of scholars' rights takes place through the courts or other government institutions. For example, Hashem Aghajari, a history professor at Tarbiat Modarres University in Tehran was convicted of apostasy by a conservative regional court and sentenced to death in 2004 for presenting an academic paper in which he described Iranian clerical rule as inconsistent with the original teachings of Islam. Although the death sentence was eventually reversed by

\section{A growing trend concerning academic freedom in} Muslim societies is an awareness of the need to address the persecution and intimidation of academics.

Iran's Supreme Court, Aghajari spent two years in jail and was only released after posting a sizable bail.

The well-known case of Egyptian scholar Nasr Hamid AbuZayd provides an example of how the Islamic legal system has been used in efforts to silence critical scholarship within the field of Islamic studies. Abu-Zayd, a former professor of Islamic studies at the University of Cairo, was put on trial by an Islamic Family Court after he published criticism of the relationship between contemporary Islamic discourse and what he called the "social and economic scandal" within Egypt's Islamic banking sector. The court declared Abu-Zayd an apostate on the grounds of his scholarly work on Qur'anic hermeneutics. It also successfully argued that it held the right to declare Abu-Zayd's marriage annulled, ostensibly to protect his Muslim wife from the sin of being married to a nonMuslim. As legal wrangling continued in his home country, Abu-Zayd and his wife immigrated to the Netherlands, where he now holds the Averroës Chair for Humanism and Islamic Studies at the University for Humanistics in Utrecht.

\section{TRENDS}

A growing trend concerning academic freedom in Muslim societies is an awareness of the need to address the persecution and intimidation of academics. Several human rights organizations are working to martial support for scholars under threat. In particular, the Scholars at Risk Network coordinates a system through which universities can offer sanctuary to scholars. Extremely important for the individuals involved, such efforts also help to reveal academic freedom violations and encourage long-term advocacy efforts by members of the international academic community in a variety of fields.
Scholars in the Netherlands have brought academic freedom issues into focus recently through a series of symposia publications (e.g., William B. Drees and Pieter Sjoerd van Koningsveld, eds. The Study of Religion and the Training of Muslim Clergy in Europe: Academic and Religious Freedom in the 21st Century, 2008). Perhaps the most significant trend is growing concern about academic freedom within Islamic education circles. Resolutions drafted by Islamic educators at the International Seminar on Religious Curricula in the Muslim World held at the International Islamic University in Kuala Lumpur, Malaysia, in September 2005 (http: //www.iiu.edu.my/iimu/info.php?infoid=26) suggest mounting frustration with the intolerance expressed by some Islamic groups. Educators there asserted the idea of broadening religious curricula and promoting freedom of thought and expression, while at the same time discouraging discussion of differences among ideological and jurisprudential schools is paradoxical. For this reason, while such resolutions do reflect progress, they also suggest that the Justinian urge to establish orthodoxy continues to thrive.

\section{China's Private Universities: A Successful Case Study}

\section{Ruth Hayhoe and Jing LiN}

Ruth Hayhoe is professor in the Department of Theory and Policy Studies, Ontario Institute for Studies in Education, University of Toronto; Jing Lin is professor in the Department of Educational Policy and Leadership, University of Maryland. Address: OISE/UT, 252 Bloor St. West, 6/F, Toronto, ON, Canada M5S 1VG. E-mail: hayhoe@bellsouth.net; Jinglin@wam.umd.edu. See also http://chinesehighereducation.org/.

$\Lambda$ s China has moved rapidly to mass higher education since Aits groundbreaking I999 decision on expansion, private universities have come to account for about 6.6 percent of student enrollments, or about I. 34 million of the 20.2 million students enrolled in formal higher education in 2006. Major public universities have also contributed, not only by expanding their regular enrollments but also by setting up second-tier colleges, which are income-generating extensions, that benefit from the university's self-accrediting status and its qualified faculty. These effective private institutions have enrollments of I.47 million students, around 7.3 percent of the total.

Given the advantaged position of second-tier colleges, how have independent private universities managed to compete? The case of Yellow River University of Science and Technology in Henan Province may provide some answers to this question. It was the first private university to enroll governmentapproved diploma students in I994 and the first to enroll 